\title{
MULTILEVEL INDEXING PADA PROSES TEMU KEMBALI DOKUMEN DIGITAL
}

\author{
Jayanta \\ Fakultas Ilmu Komputer, Program Studi Teknik Informatika \\ Universitas Pembangunan Nasional Veteran Jakarta \\ Email: anta.jayanta@gmail.com \\ Titin Pramiyati \\ Sistem Informasi \\ Universitas Pembangunan Nasional Veteran Jakarta \\ titin.harsono@gmail.com
}

\begin{abstract}
ABSTRAK
Dokumen digital adalah sebuah konsep pengumpulan, penyimpanan dan pengelolaan informasi dalam bentuk cetakan atau gambar elektronik yang dapat dipakai sebagai bukti atau keterangan. Penggunaan dokumen digital yang dianggap lebih efisien dalam pengiriman dokumen terkait dengan kemudahan akses, dan temu kembali dokumen menjadikan dokumen digital menjadi alternatif yang digunakan pada proses administrasi kegiatan tri darma perguruan tinggi tenaga pendidik. Pengambilan kembali dokumen menjadi kemudahan tersendiri ketika dokumen-dokumen disimpan dalam bentuk elektronik yang dapat digunakan kepada pengguna dokumen baik individual maupun organisasi. Penyediaan kemudahan mendapatkan kembali dokumen kegiatan tri darma perguruan tinggi yang dilakukan oleh tenaga pendidik merupakan masalah yang dibahas dalam penelitian yang dilakukan. Permasalahan dalam pencarian dokumen ini dapat diselesaikan dengan membuat mekanisme pencarian dokumen secara otomatis dengan memanfaatkan multilevel indexing pada penyimpanan dokumen yang diorganisasikan berdasarkan kategori menjadi topik dalam pembahasan makalah ini. Metode yang dilakukan pada penelitian ini terdiri dari tahap analisis penyimpanan dokumen digital tenaga pendidik, analisis penggunaan multilevel indexing untuk penanganan temu kembali dokumen tenaga pendidik, tahap penyiapan aplikasi temu kembali, dan tahap ujicoba. Hasil yang diperoleh adalah implementasi pencarian dokumen digital tenaga pendidik menggunakan multilevel indexing, dalam bentuk aplikasi temu kembali yang fleksibel.
\end{abstract}

Kata kunci: dokumen digital, temu kembali dokumen, multilevel indexing.

\begin{abstract}
Digital documents are a concept of collecting, storing and managing information. This document may be in the form of electronic prints or images that may be used as evidence, and information. There is the assumption that the use of digital documents can be more efficient in accessing, reusing documents, and sending documents. The search for digital documents automatically becomes an alternative in providing access services to the document of "Tri Darma Perguruan Tinggi" when the document will be reused. Retrieving documents easily is a topic discussed in this research. Application development to retrieve documents by applying multilevel indexing techniques becomes an option to resolve document retrieval issues. Multilevel indexing techniques are used because the documents to be searched are organized in categorization, therefore indexing is required. The method used in this research consisted of analysis phase of digital document storage, multilevel indexing usage analysis for document retrieval, preparation phase of retrieval document application, and test phase. The results obtained are applications that implement digital document search for educators using multilevel indexing.
\end{abstract}

Keywords: digital document, document retrieval, multilevel indexing.

\section{PENDAHULUAN}

Dokumen digital dalam proses administrasi di bidang akademik khususnya administrasi bagi tenaga pendidik sangat penting, hal ini dikarenakan tenaga pendidik yang terdaftar sebagai tenaga tetap harus melengkapi dokumen akademik yang dimiliki dalam bentuk elektronik. Dokumen dalam bentuk digital juga dibutuhkan dalam proses administrasi tri darma perguruan tinggi yang dilakukan oleh tenaga pendidik, seperti kegiatan penelitian pada situs sistem penelitian dan pengabdian kepada masyarakat 
(simlitabmas) pendidikan tinggi, yang mengharuskan tenaga pendidik menggunakan dokumen digital dalam penyampaian proposal penelitian dan pengabdian yang diajukan [1]. Kebutuhan yang sangat penting terhadap ketersediaan dokumen digital tenaga pendidik adalah pada proses pembuktian beban kinerja dosen yang harus dilaporkan secara berkala tiap semester yang meliputi kegiatan tri darma perguruan tinggi.

Dokumen digital dapat berfungsi sebagai arsip dalam format elektronik. Arsip merupakan salah satu sumber informasi yang penting bagi suatu organisasi. Infomasi yang berkaitan dengan perkembangan dan kegiatan operasional suatu organisasi akan senantiasa terjaga seiring dengan terjaganya arsip organisasi tersebut. Arsip bagi suatu organisasi tidak sekedar menjadi bukti sejarah, tetapi memiliki berbagai fungsi dan nilai guna. Arsip akan dibutuhkan oleh pimpinan sebagai bahan pertimbangan dalam mengambil keputusan organisasi [2].

Berdasarkan pada peran dokumen digital dalam pengambilan keputusan dan fungsi dokumen kegiatan tri darma yang dapat digunakan untuk berbagai tujuan seperti akreditasi, pembuatan laporan beban kinerja dosen, peningkatan karier dosen dan kebutuhan lain, menjadi latar belakang dilakukan penelitian untuk membuat teknik pencarian dokumen digital dengan memperhatikan cara penyimpanan dokumen. Sistem informasi tenaga pendidik (SIT-Didik) UPNVJ [3] adalah sistem informasi dokumen digital kegiatan tri darma perguruan tinggi di Universitas Pembangunan Nasional Veteran Jakarta (UPNVJ). Teknik penyimpanan dokumen digital pada SIT-Didik menggunakan teknik kategori dengan mengadaptasi teknik penyimpanan file dalam directory. Teknik penyimpanan dokumen SIT-Didik digunakan sebagai studi kasus pada penelitian ini dikarenakan SIT-Didik mengorganisasikan dokumen digital tenaga pendidik dengan konsep tree (pohon) untuk mendukung mekanisme pencarian yang terstruktur [4].

Penyimpanan dokumen digital pada SIT-Didik diorganisasikan berdasarkan kategori, dengan Nomor Induk Dosen Nasional (NIDN) sebagai kategori root, yang secara berurut diikuti oleh kategori kegiatan dari tri darma, sub kategori tri darma, tipe dokumen, dan koleksi dokumen (file) seperti terlihat pada Gambar 12. Berkas yang disimpan merupakan dokumen yang dibedakan sesuai dengan jenis surat, seperti surat keputusan, sertifikat, atau jenis surat lainnya.

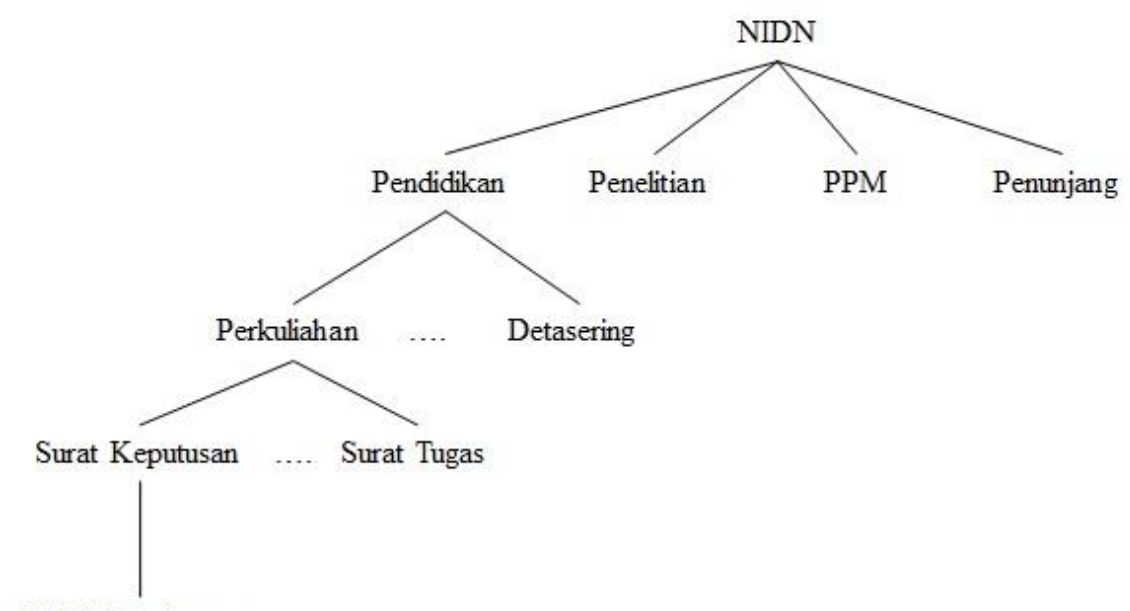

Koleksi Dokumen

\section{Gambar 12. Struktur Pohon Organisasi Penyimpanan Dokumen SIT-Didik}

SIT-Didik dibangun untuk memberi kemudahan kepada tenaga pendidik dalam mengumpulkan, menyimpan dan memelihara berkas kegiatan darma pendidikan, penelitian, pengabdian pada masyarakat (PPM), dan kegiatan penunjang. ketersediaan dokumen digital akan memberikan informasi yang lengkap tentang kegiatan tri darma tenaga pendidik, sehingga dapat membantu dalam kegiatan peningkatan karir, pelaporan kegiatan tenaga pendidik, pengendalian kegiatan tri darma perguruan tinggi, dan distribusi data akademik tenaga pendidik. Penyediaan dokumen digital dimaksudkan agar pengelolaan materi-materi tersebut dapat menjadi lebih baik dan efisien sekaligus sebagai sarana knowledge repository, dan knowledge sharing [5].

Temu kembali dokumen pada penyimpanan dokumen yang diorganisasikan secara berkategori merupakan permasalahan yang dijadikan topik makalah ini. Temu kembali dokumen dengan teknik pencarian menggunakan pendekatan peng-indeksan menjadi pilihan untuk menyelesaikan permasalahan. Teknik pengindeksan yang digunakan adalah multilevel indexing yang menyimpan data indeks dalam file database, sehingga data indeks menjadi lebih ringkas. 
Hasil yang diperoleh dari implementasi temu kembali dokumen menggunakan multilevel indexing memberikan kemudahan kepada pengguna sistem untuk mendapatkan kembali dokumen digital pada media simpanan, dan teknik pengindeksan multilevel menjadikan penambahan indeks untuk kebutuhan dengan penambahan kategori, sub kategori, tipe dokumen, dan koleksi dokumen menjadi lebih mudah.

\section{METODOLOGI PENELITIAN}

Tahapan yang dilakukan pada penelitian ini terdiri dari tahap analisis penyimpanan dokumen digital tenaga pendidik, analisis penggunaan multilevel indexing untuk penanganan temu kembali dokumen tenaga pendidik, tahap penyiapan aplikasi temu kembali, dan tahap ujicoba, seperti terlihat pada Gambar 13. Tahap analisis penyimpanan dokumen digital tenaga pendidik dilakukan untuk menentukan teknik temu kembali dokumen yang disesuaikan dengan teknik penyimpanan dokumen yang terdapat pada SITDidik. Teknik temu kembali dokumen yang dianalisis adalah pencarian dokumen berdasarkan kata kunci, dan pencarian dokumen berdasarkan indeks. Tahap analisis penggunaan multilevel indexing untuk penanganan temu kembali dokumen tenaga pendidik dilakukan untuk menentukan apakah pengindeksan multilevel dapat digunakan sebagai teknik pencarian dokumen.

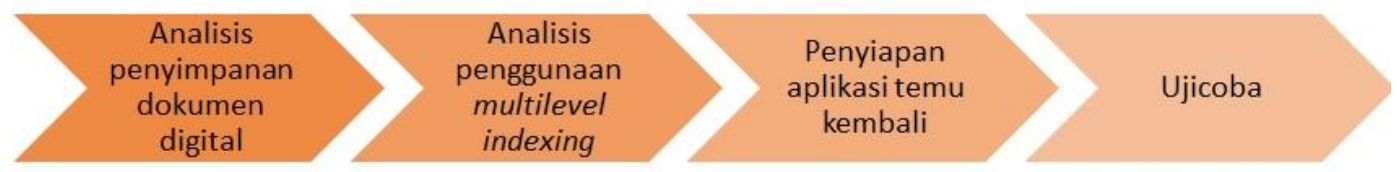

Gambar 13. Metode Penelitian

Tahap penyiapan aplikasi temu kembali yang dilakukan adalah tahap pembangunan aplikasi temu kembali menggunakan teknik pengindeksan multilevel yang mudah digunakan, pada tahap ini antar muka (interface) yang dibuat masih belum memperhatikan estetika antar muka. Tahap ini juga dibangun dengan memperhatikan kemudahan dalam penambahan jenis kaegori, sub kategori, dan jenis dokumen yang disimpan. Tahap ujicoba adalah pengujian terhadap aplikasi yang dibuat. Hasil akhir dari penelitian ini adalah aplikasi temu kembali dokumen digital yang sesuai dengan teknik penyimpanan dokumen berkategori. Aplikasi yang dihasilkan cukup fleksibel dalam penambahan spesifikasi kategori, sub kategori, dan jenis surat.

\section{HASIL DAN PEMBAHASAN}

Sistem Temu Kembali Informasi adalah teknik mencari informasi dalam suatu dokumen, mencari dokumen itu sendiri, dan mencari metadata yang menggambarkan suatu dokumen. Sistem ini berkonsentrasi pada representasi, penyimpanan, pengorganisasian, akses, dan distribusi informasi [6]. Fungsi dari sistem temu kembali informasi adalah membantu pencarian informasi dengan memberikan kumpulan informasi yang sesuai dengan kebutuhan pengguna. Sistem temu-kembali informasi dibuat dengan teknik pencarian dokumen atau informasi berdasarkan pada permintaan pengguna berupa query, dan jawaban dari permintaan tersebut adalah sekumpulan dokumen yang relevan.

Teknik pencarian dokumen dilakukan pada kumpulan dokumen yang sudah ditentukan indeksnya terlebih dahulu dan ditempatkan pada basisdata. Berdasarkan indeks ini akan dilakukan pencarian dokumen yang relevan. Pencarian dokumen dilakukan berdasarkan pada permintaan (request) yang diubah menjadi query melalui proses operasi teks sehingga akan diperoleh term index yang digunakan untuk mendapatkan indeks koleksi. Hasil pencarian akan diberikan dalam bentuk kumpulan dokumen yang relevan dengan query dan telah dirangking, sebagaimana terlihat pada Gambar 14. Sistem temu kembali dokumen pada dasarnya dibagi dalam dua komponen utama yaitu sistem pengindeksan (indexing) yang menghasilkan database sistem, dan proses temu kembali yang merupakan gabungan dari user interface dan look-up-table. 


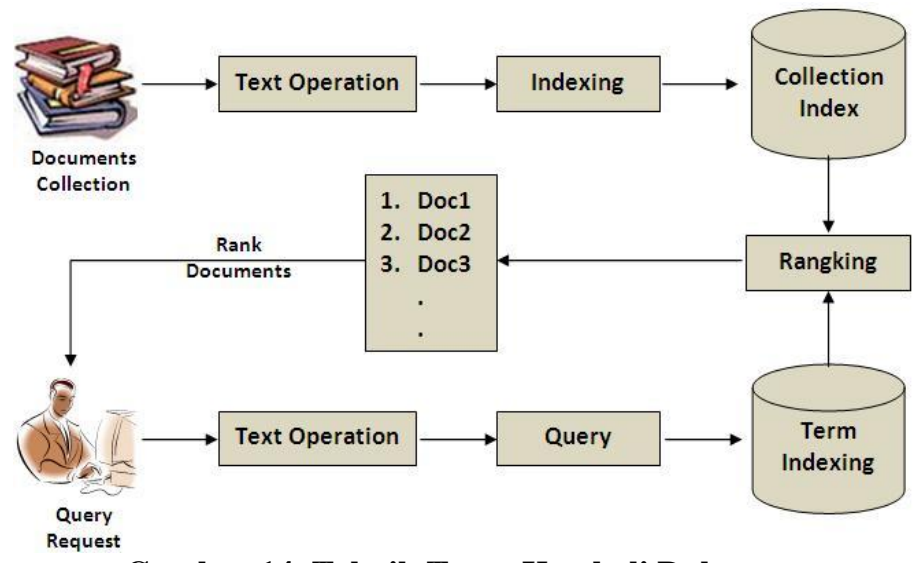

Gambar 14. Teknik Temu Kembali Dokumen

Saat ini, dokumen digital digunakan atas kesadaran adanya upaya untuk mengurangi penggunaan kertas, kemudahan penyimpanan dokumen, pencarian kembali dokumen yang lebih efisien, dan penghematan biaya pemeliharaan dokumen. Dokumen kegiatan tri darma yang dilakukan tenaga pendidik dapat disiapkan dalam bentuk digital menjadi suatu keharusan. Penyimpanan dokumen pada media elektronik seperti hard disk dalam komputer, membutuhkan pengelolaan dokumen digital karena selain menyangkut tempat penyimpanan juga menyangkut mendapatkan kembali (retrieval) dokumen apabila akan digunakan atau dilakukan pencarian (search) terhadap dokumen tersebut.

Sistem manajemen dokumen merupakan sistem berbasis komputer yang menyediakan penyimpanan dokumen digital berbasis web yang dapat diakses dari berbagai tempat [7]. Sistem manajemen dokumen menyediakan tempat penyimpanan yang terpusat (centralized repository). Sistem manajemen dokumen bermanfaat dalam mengefektifkan dan mengefisienkan proses bisnis. Manfaat utama dari sistem manajemen dokumen adalah pengguna dapat menemukan informasi yang dibutuhkan dengan cepat, sehingga proses menjadi lebih cepat, baik dan murah [8].

Indexing (pengindeksan) adalah sebuah teknik struktur data yang digunakan untuk mengefisienkan pengambilan record dari file database berdasarkan pada beberapa atribut yang telah diindeks. Pengindeksan pada sistem database sama seperti apa yang kita lihat pada pengindeksan buku. Indeks record terdiri dari nilai search-key dan pointer (penunjuk data). Pengindeksan multilevel (multilevel index) disimpan bersama dengan file database dalam satu media simpanan. Ukuran indeks akan meningkat seiring dengan peningkatan basisdata dimana indeks tersebut digunakan. Kebutuhan penyimpanan indeks rekord pada memori utama bertujuan untuk mempercepat proses penyimpanan. Pengindeksan multilevel membantu dalam memecah pengindeksan yang berukuran besar menjadi beberapa indeks yang lebih kecil. Pengindeksan multilevel membentuk indeks terluar dengan ukuran yang kecil sehingga bisa disimpan dalam satu blok disk, yang dapat dengan mudah diakomodasi dimana saja di memori utama, Gambar 15. memperlihatkan ilustrasi pengindeksan multilevel.

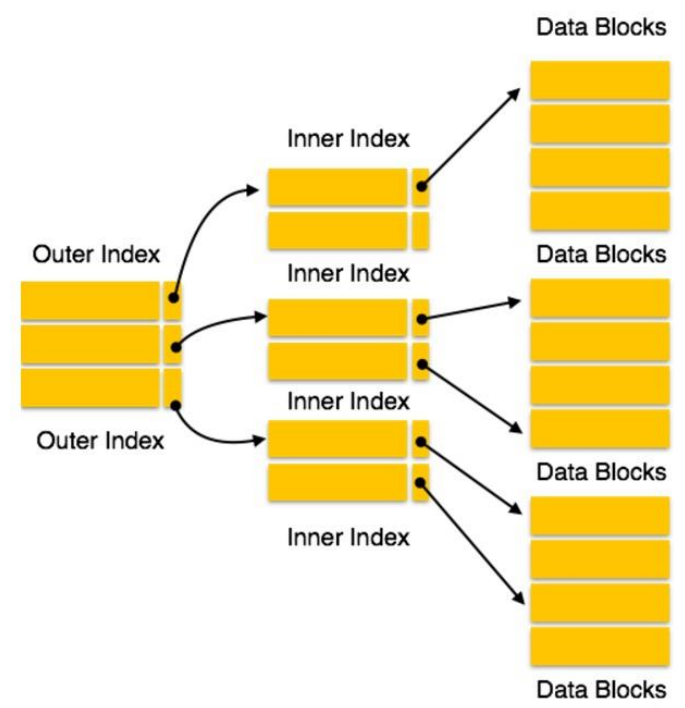

Gambar 15. Pengindeksan Multilevel (sumber: https://www.tutorialspoint.com/dbms/dbms_indexing.htm) 
Teknik penyimpanan dokumen digital pada SIT-Didik menggunakan teknik penyimpanan sebagaimana teknik penyimpanan file yang disimpan pada directory/folder. Nama kategori yang dijadikan sebagai root adalah NIDN tenaga pendidik. NIDN/NIK ini akan memiliki 4 sub kategori, yaitu kategori Pendidikan, Penelitian, PPM, dan Penunjang. Setiap sub kategori akan memiliki sub-sub kategori yang merupakan kegiatan tri darma sesuai dengan ketentuan, seperti terlihat pada Gambar 16.

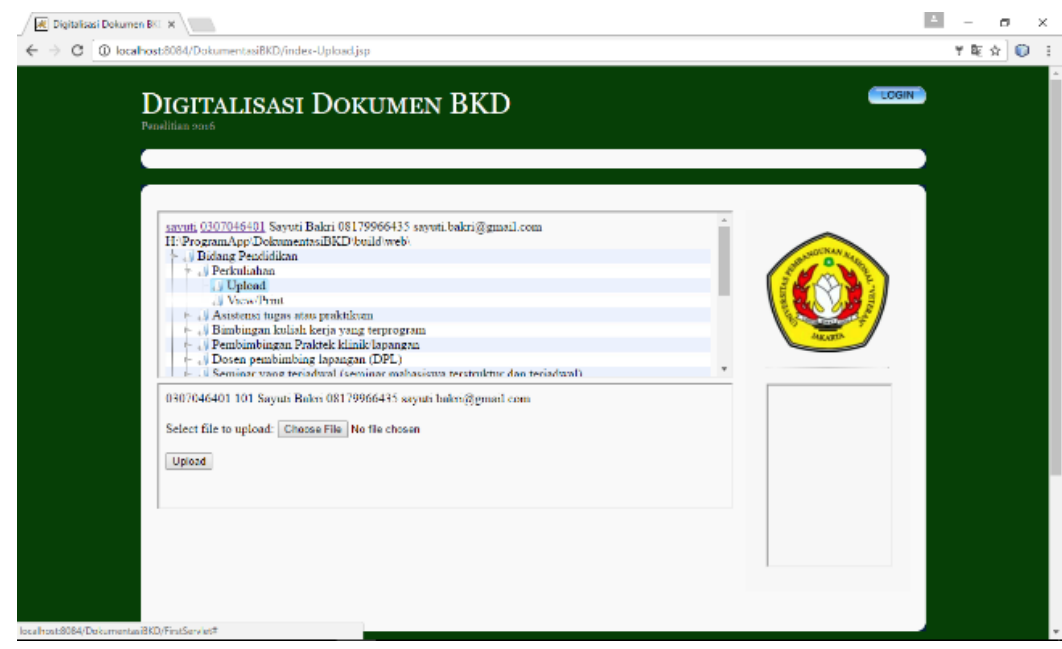

Gambar 16. Teknik Penyimpanan Dokumen SIT-Didik

\subsection{Tahap Analisis Teknik Pencarian Dokumen}

Tahap analisis untuk menentukan teknik pencarian dokumen yang digunakan terdiri dari analisis teknik pencarian menggunakan kata kunci dan indeks. Analisis teknik pencarian menggunakan kata kunci menghasilkan beberapa pertimbangan, seperti penggunaan format tertentu untuk nama file dokumen, penggunaan kombinasi kata kunci, dan beberapa hambatan operasional yang akan ditemui. Hasil analisis terkait dengan penggunaan kata kunci sebagai dasar dalam pencarian dokumen adalah kebutuhan akan struktur nama dokumen sebagai sebagai nama file yang berisi semua kategori. Struktur nama yang dibentuk terdiri dari kombinasi urutan kategori, masa dokumen (tahun dan semester saat dokumen dikeluarkan). Penggunaan struktur ini tidak memberikan kemudahan dan kenyamanan kepada pengguna.

Tabel 1. Format kata kunci

\begin{tabular}{|c|c|c|c|c|}
\hline \multicolumn{3}{|c|}{ Jenis format } & Kombinasi format & \multirow[t]{2}{*}{ Pengguna } \\
\hline Unary & (menggunakan satu & kata & Posisi-1 & \\
\hline kunci) & & & Posisi-2 & Admin \\
\hline & & & Posisi-3 & Admin \\
\hline & & & Posisi-4 & Admin, TP (tenaga pendidik) \\
\hline \multirow{6}{*}{$\begin{array}{l}\text { Binary } \\
\text { kunci) }\end{array}$} & (menggunakan dua & kata & Posisi-1 + Posisi-2 & Admin \\
\hline & & & Posisi-1 + Posisi-3 & Admin \\
\hline & & & Posisi-1 + Posisi-4 & Admin, TP (tenaga pendidik) \\
\hline & & & Posisi-2 + Posisi-3 & Admin \\
\hline & & & Posisi-2 + Posisi-4 & Admin, TP (tenaga pendidik) \\
\hline & & & Posisi-3 + Posisi-4 & Admin, TP (tenaga pendidik) \\
\hline 3-ary & (menggunakan dua & kata & Posisi-1 + Posisi-2 + Posisi-3 & Admin, TP (tenaga pendidik) \\
\hline kunci) & & & Posisi-1 + Posisi-2 + Posisi-4 & Admin, TP (tenaga pendidik) \\
\hline & & & Posisi-1 + Posisi-3 + Posisi-4 & Admin, TP (tenaga pendidik) \\
\hline & & & Posisi-2 + Posisi-3 + Posisi-4 & Admin, TP (tenaga pendidik) \\
\hline $\begin{array}{l}\text { 4-ary } \\
\text { kunci) }\end{array}$ & (menggunakan dua & kata & $\begin{array}{l}\text { Posisi-1 + Posisi-2 + Posisi-3 }+ \\
\text { Posisi-4 }\end{array}$ & Admin, TP (tenaga pendidik) \\
\hline
\end{tabular}

Penggunaan kata kunci dalam pencarian dokumen menggunakan format kata kunci satu kata (unigram), format kata kunci 2 kata (bigram), 3-gram, dan 4-gram sebagaimana terlihat pada Tabel 1. Penggunaan kata kunci dapat memudahkan pengguna untuk dalam proses pencarian, akan tetapi pengguna harus memahami struktur nama dokumen yang digunakan. Penggunaan kata kunci dalam teknik pencarian dokumen ini memiliki potensi adanya hambatan operasional yang berkaitan dengan pemberian nama dokumen yang harus dilakukan oleh pengguna. 
Analisis penggunaan indeks dalam pencarian dokumen, dimana indeks menjadi search-key dan pointer bagi dokumen dan ditempatkan dalam file. Analisis ini menghasilkan pertimbangan bahwa teknik pengindeksan yang digunakan harus sesuai dengan teknik penyimpanan dokumen yang digunakan pada SIT-Didik. Teknik pengindeksan yang digunakan adalah multilevel indexing dengan tingkatan pengindeksan dimulai dari kategori, sub-kategori dan seterusnya sesuai dengan pedoman beban kerja dosen [9] yang masih relevan dijadikan sebagai acuan. Teknik pencarian ini tidak mengharuskan nama dokumen dengan format tertentu sehingga tenaga pendidik dapat dengan mudah mencari dokumen yang diinginkan.

\subsection{Tahap Analisis Penggunakan Multilevel Indexing Pada Pencarian Dokumen Digital}

Tahap analisis penggunaan indeks dalam pencarian dokumen, menghasilkan keputusan bahwa pengindeksan yang digunakan adalah multilevel indexing. Penggunaan pengindeksan ini didasarkan pada teknik penyimpanan dokumen yang berkategori membutuhkan adanya pengindeksan yang bertingkat. Level indeks terluar berada pada root kategori, yaitu NIDN/NIK. Ilustrasi pengindeksan multilevel pada aplikasi ini terlihat pada Gambar 17.

Multilevel indexing memungkinkan setiap kategori memiliki blok indeks, seperti terlihat pada Gambar 17., kata kunci yang merupakan tipe_dokumen akan dibuat blok indeks terdiri kata kunci dan pointer. Pointer pada blok indeks ini digunakan untuk menunjuk ke pointer pada indeks tipe-dokumen. Pointer pada blok indeks tipe_dokumen inilah yang digunakan untuk mendapatkan kumpulan dokumen oleh tenaga pendidik.

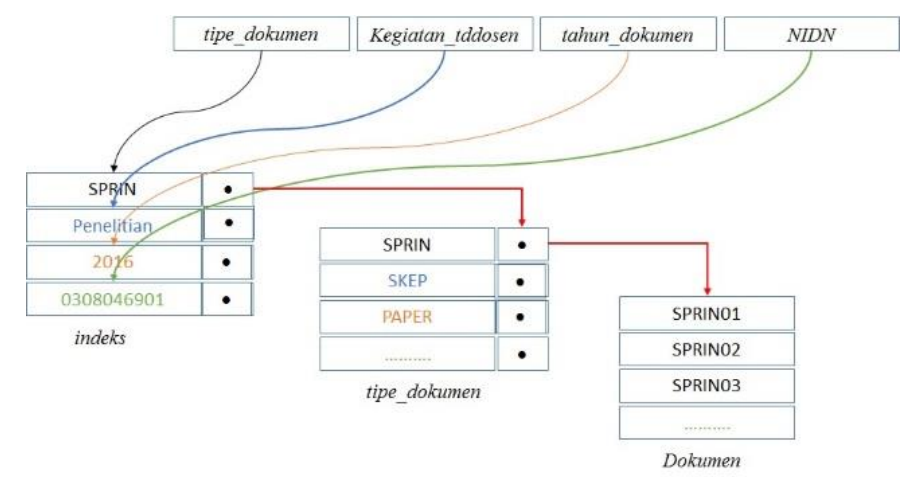

\section{Gambar 17. Ilustrasi Multilevel Indexing Pada Pencarian Dokuem SIT-Didik}

\subsection{Penyiapan Aplikasi Temu Kembali}

Tahap selanjutnya yang dilakukan adalah penyiapan aplikasi, dimana tahap ini merupakan kegiatan pembangunan aplikasi untuk kebutuhan ujicoba. Konstruksi aplikasi temu kembali ini masih sederhana, seperti terlihat pada Gambar 18., merupakan antar muka yang digunakan untuk melakukan pencarian dokumen. Pencarian dokumen dapat dilakukan oleh pengguna berdasarkan jenjang kategori, dengan pilihan awal (default) adalah "semua kategori”.

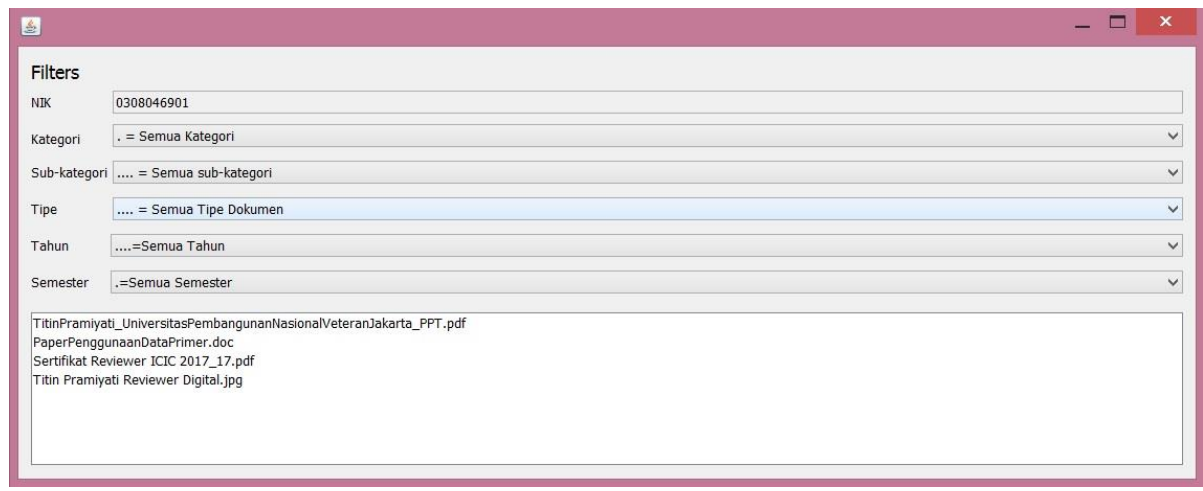

Gambar 18. Antar-Muka Aplikasi Pencarian Dokumen

Antar muka pencarian dokumen juga memudahkan pengguna dalam pencarian dokumen tertentu. Pencarian dokumen tertentu dapat dilakukan melalui proses penentuan kategori, subkategori, dan tipe dokumen seperti pada potongan program berikut: 


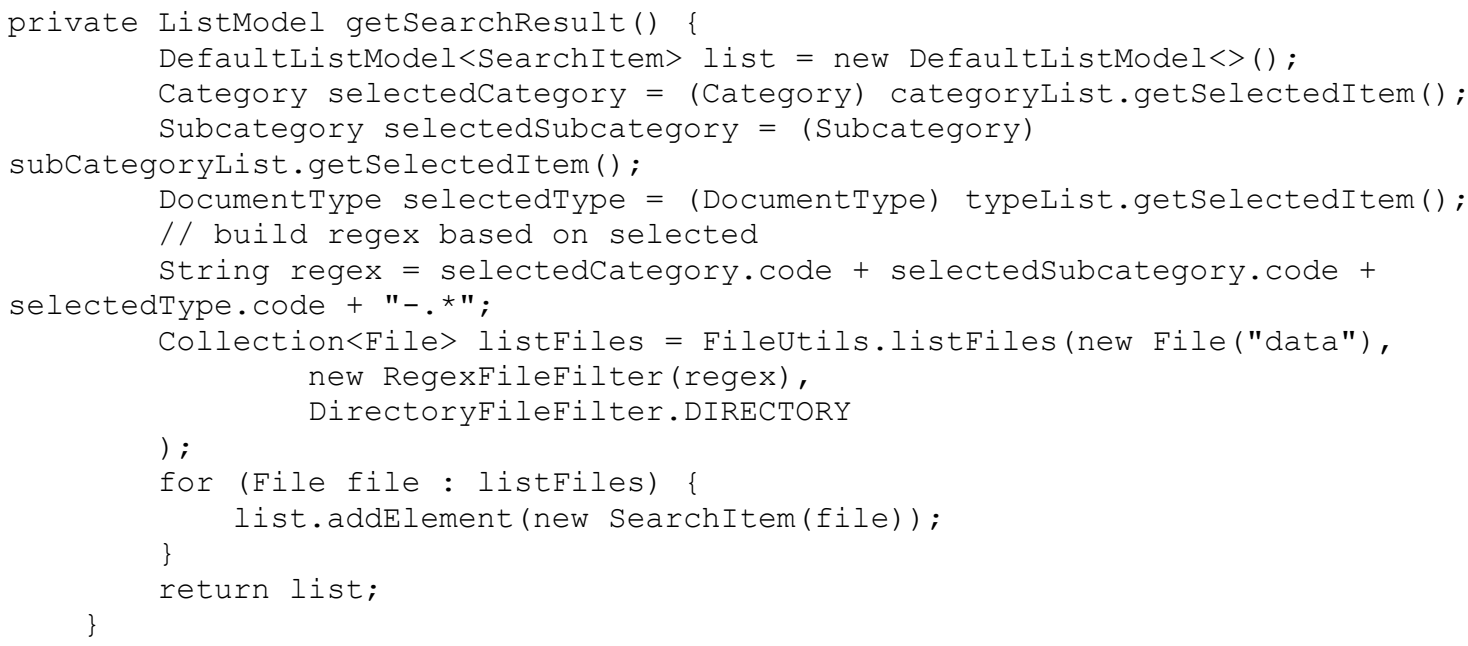

Pemilihan kategori, sub kategori, dan tipe dokumen akan menjadi bagian dari struktur indeks yang dibangun dan sekaligus untuk membentuk folder dimana dokumen ditempatkan. Teknik ini memungkinkan pembangunan folder disesuaikan dengan kategori dari dokumen yang disimpan. Indeks yang terbentuk akan disatukan dengan nama berkas dari dokumen yang disimpan, dan akan terbentuk nama berkas baru seperti ini: B1000JI_201510308046901-411-1068-1-PB. Nama asli dari dokumen pada struktur indeks diletakan pada posisi setelah NIDN/NIK pengguna (0308046901). Nama berkas ini akan menjadi outer index dalam proses pencarian dokumen.

Tipe dokumen yang dapat disimpan pada aplikasi tidak dibatasi tipenya, oleh karenanya aplikasi ini menyediakan fasilitas untuk menambah dan mengurangi kategori, sub kategori, atau tipe dokumen. Teknik untuk fasilitas ini dilakukan dengan cara menulis tipe dokumen yang akan ditambahkan pada sebuah berkas berekstensi .txt yang akan dibaca oleh program. Isi berkas type.txt yang digunakan untuk kebutuhan pengelompokan tipe dokumen yang disimpan adalah sebagai berikut:

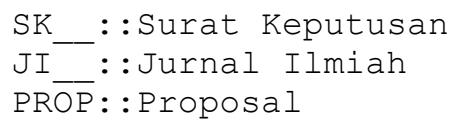

Berkas type.txt ini juga berfungsi untuk kebutuhan pembatasan tipe dokumen yang dapat disimpan, sehingga pengguna tidak dapat menyimpan dokumen yang tidak sesuai dengan ketentuan. Berikut ini adalah proses inisialisasi data sesuai dengan kategori dan tipe dokumen berdasarkan berkas categories.txt dan type.txt.

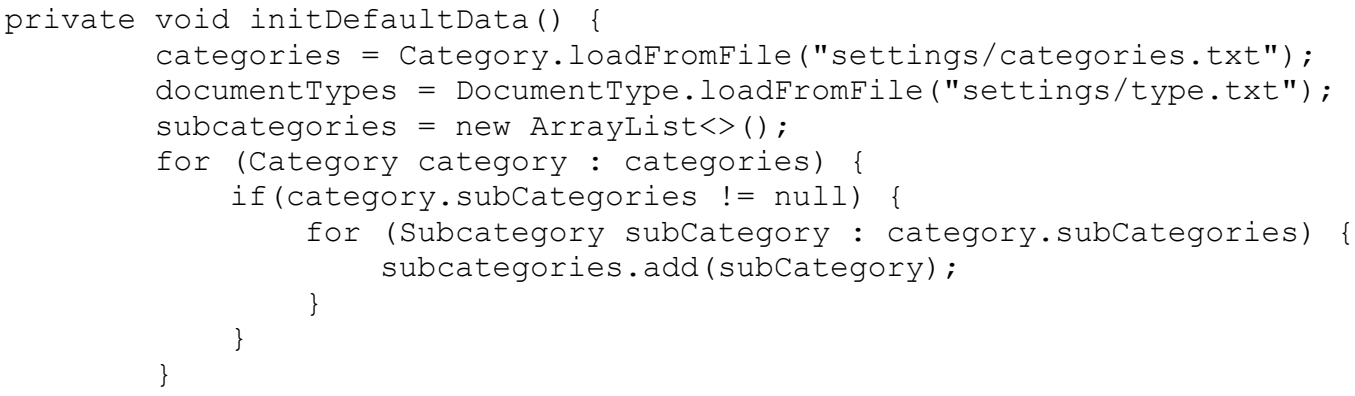

\subsection{Ujicoba Aplikasi}

Ujicoba aplikasi temu kembali dilakukan secara terpisah dari SIT-Didik, sehingga untuk melakukan pencarian dokumen terlebih dahulu dilakukan penyimpanan dokumen untuk mengetahui pembentukan indeks dan folder dokumen yang telah ditentukan. Hasil dari proses penyimpanan seperti terlihat pada

Gambar 19. Tipe dokumen yang disimpan adalah dokumen proposal dengan tahun dari dokumen adalah 2016 pada semester genap. Dokumen ini merupakan kegiatan darma penelitian (B). 


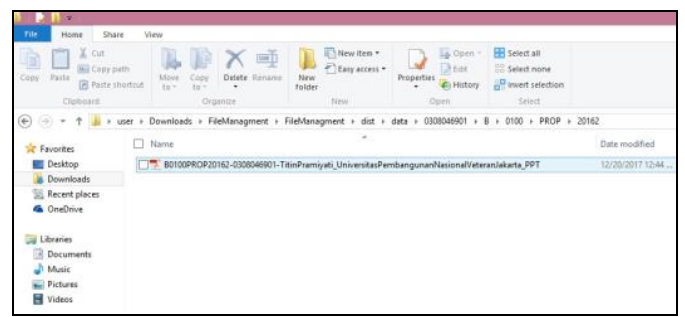

Gambar 19. Hasil Ujicoba Menyimpanan Dokumen

Ujicoba pencarian dokumen dilakukan dengan berbagai kebutuhan pencarian, dan berikut ini adalah hasil ujicoba tersebut:

a. Pilihan awal yang ditetapkan adalah "semua kategori" menampilkan semua dokumen yang telah disimpan, seperti terlihat pada Gambar 18. Penggunaan pilihan ini akan memberikan informasi yang cepat karena semua dokumen akan ditampilkan. Pilihan "semua kategori" akan memberikan pencarian yang efisien jika pengguna terbiasa menggunakan nama berkas yang terstruktur sehingga mudah diingat oleh pengguna.

b. Pilihan pencarian dokumen sesuai kategori akan membantu pencarian pada saat dokumen yang tersimpan telah banyak sehingga tidak dapat ditampilkan dalam satu layar. Pilihan ini juga akan membantu pengguna yang tidak terbiasa menggunakan nama berkas yang mudah diingat.

Nama berkas yang ditampilkan pada proses pencarian tidak menyertakan indeks yang dibentuk sehingga memberi kemudahan kepada pengguna untuk memilih berkas yang dicari. Jika nama berkas yang ditampilkan seperti pada

c. Gambar 19., akan membuat pengguna kesulitan, karena nama berkas yang terlalu panjang.

d. Akses langsung ke dokumen tanpa melalui mekanisme menu download pada antar muka aplikasi temu kembali memberi kemudahan kepada pengguna untuk dapat memastikan kebenaran isi dokumen.

\section{KESIMPULAN}

Multilevel indexing dapat digunakan sebagai dasar pencarian dokumen digital yang disimpan menggunakan teknik penyimpanan directory/folder. Aplikasi temu kembali yang dirancang dengan untuk pencarian dokumen dapat dioperasikan dengan mudah, dan pemilihan kategori, sub kategori, dan seterusnya dapat mengarahkan pengguna untuk mendapatkan dokumen yang dicari dengan benar.

\section{UCAPAN TERIMA KASIH}

Kami mengucapkan terimakasih kepada UPN Veteran Jakarta yang telah memberi dana bantuan penelitian sehingga penelitian ini dapat diselesaikan.

\section{DAFTAR PUSTAKA}

[1] DRPM Kemristekdikti. (2016). Panduan Pelaksanaan Penelitian dan Pengabdian kepada Masyarakat di Perguruan Tinggi Edisi X Tahun 2016. Edisi X. 2. DRPM Kemristekdikti.

[2] Sutirman (2015). "Manajemen Arsip Elektronik". Lab. Adm. Perkantoran FE UNY. pp. 1-8.

[3] S. Bakri, H. Mahfud, and T. Pramiyati. (2017). "Dokumentasi Digital: Aplikasi Penyimpanan dan Pengambilan Dokumen Digital Tenaga Pendidik”. Prosiding Seminar Nasional Teknologi Informasi dan Multimedia (Semnasteknomedia) 2017. 2017th ed. pp. 79-83.

[4] H. Meuss and C. M. Strohmaier. (1999). "Improving Index Structures for Structured Document Retrieval". 21st BCS IRSG Colloquium on IR. pp. 1-14.

[5] F. Panduwinata. (2010). "Perancangan Sistem Manajemen Dokumen Elektronik Untuk Materi elearning Sebagai Sarana Knowledge Repository dan Knowledge Sharing”. Seminar Ilmiah Nasional Kommit.

[6] A. Wibowo. (2011). "Pengujian Kerelevanan Sistem Temu Kembali Informasi," Semin. Nas. Ilmu Komput. no. 1.pp. 1-8.

[7] E. M. Awad, and H. M. Ghaziri. (2004). Knowledge Management. Pearson Education. Inc.

[8] T. Suryana and D. Florence. (2013)."Sistem Manajemen Dokumen," Komputa-Jurnal Ilmiah Komputer dan Informatika. Vol.1 pp. 1-16.

[9] D. P. Dirjen DIKTI. (2010). Pedoman beban kerja dosen dan evaluasi pelaksanaan tridharma perguruan tinggi. 